\title{
Analisis Mutu Pelayanan Dokter Umum Terhadap Kepuasan Pasien BPJS Rawat Inap Di RSUD Praya
}

\author{
Irmawati $^{1)}$, Saimi $^{2)}$, Heru Purnama ${ }^{2)}$ \\ Email: irmawatibin212@gmail.com \\ 1) Mahasiswa Prodi D3 Perekam Medik dan Informasi Kesehatan / Universitas Qamarul Huda \\ Badaruddin Bagu \\ 2) Program Perekam Medik dan Informasi Kesehatan / Universitas Qamarul Huda Badaruddin Bagu
}

\begin{abstract}
ABSTRAK
Penelitian ini bertujuan untuk mengetahui mutu pelayanan dokter terhadap kepuasaan pasien BPJS di pelayanan rawat inap Rumah Sakit Umum Daerah Praya. Mutu pelayanan kesehatan merujuk pada tingkatan kesempurnaan penampilan layanan kesehatan yang diselenggarakan untuk memuaskan pemakai - pemakai jasa pelayanan yang tata cara penyelenggaraannya sesuai dengan kode etik profesi serta standar yang telah ditetapkan. Hasil pengamatan dan wawancara menggambarkan bahwa tingkat kepuasan pasien dapat dijelaskan berdasarkan tingkat kehandalan, daya tanggap, asuransi dan empathy. Hasil identifikasi menunjukkan bahwa tingkat kepuasan pasien terhadap pelayanan dokter dari segi keandalan, daya tanggap, asuransi dan empathy dapat dikelomopkkan dalam kategori pasien yang sangat puas, pasien puas, pasien yang tidak puas dan pasien yang sangat tidak puas. Dalam melayani pasien dokter umum harus lebih memperhatikan tentang kualitas pelayanan yang diberikan kepada pasien agar rumah sakit semakin berkembang dan untuk petugas ruangan rawat inap penyakit dalam harus lebih sigap dalam mersepon pasien, dokter harus selalu menerapkan senyum, salam, sapa, sopan dan santun setiap melayani pasien.
\end{abstract}

Kata kunci: Mutu Pelayanan, Kepuasan Pasien, BPJS .

\begin{abstract}
Patient satisfaction is an important key in improving quality care in health services. The formulation of the problem is how the quality of medical services to patient satisfaction BPJS in hospitalization of internal medicine in Praya Regional General Hospital. The purpose of this study is to investigate the quality of service of the doctor to patient satisfaction of BPJS in the Praya Regional Public Hospital. The quality of health services is to refer to the level of perfection of the performance of health services held on the one hand to satisfy the users of the service and on the other hand the procedures of implementation in accordance with the professional code of ethics and standards that have been set. The results of identification shows that the level of patient satisfaction on the service of physicians in terms of reliability, responsiveness, insurance and empathy can be categorized in the highly satisfied patients, satisfied patients, dissatisfied patients and patients who are very dissatisfied. In the service of patients, the doctor should pay more attention to the quality of services provided to patients, and the impatient care personel should be more alert in calling patients, doctors should always smile, regards, greetings, courtesy and polite for serving the patients.
\end{abstract}

Keywords: Quality of Service, Patient Satisfaction, BPJS.

\section{A. LATAR BELAKANG}

Rumah sakit adalah fasilitas pelayanan kesehatan yang bertujuan untuk menyediakan layanan kesehatan baik rawat inap maupun rawat darurat. Pelayanan pasien adalah hal penting yang 
terdapat di rumah sakit. Pelayanan yang baik akan berdampak pada meningkatnya mutu pelayanan kesehatan dan kepuasan pasien. Kepuasan pasien adalah determinan dalam peningkatkan quality care dalam pelayanan kesehatan. Pasien yang puas akan menggunakan jasa layanan kesehatan tersebut kembali serta merekomendasikannya pada orang lain. Pelayanan baik yang diberikan petugas kesehatan kepada pasien, baik itu pasien umum maupun pasien dengan jaminan sosial seperti pasien BPJS akan selalu merasa puas terhadap pelayanan yang telah diberikan.

Berdasarkan hasil studi pendahuluan yang dilakukan di Rumah Sakit Umum Daerah Praya yang menggunakan data pasien di dua bangsal sebanyak 88 data pasien, ditemukan tingkat kepuasan pasien secara umum terhadap pelayanan dokter di bangsal pertama sebesar $80 \%$ puas dan $20 \%$ tidak puas sedangkan tingkat kepuasan pasien secara umum terhadap pelayanan dokter di bangsal kedua sebesar $75 \%$ puas dan $25 \%$ tidak puas. Berdasarkan data di atas peneliti tertarik untuk mengidentifikasi tingkat kepuasan pasien BPJS terhadap pelayanan dokter di rawat inap penyakit dalam Rumah Sakit Umum Daerah Praya dan mengidentifikasi pelayanan dokter pada pasien BPJS di rawat inap penyakit dalam di Rumah Sakit Umum Daerah Praya.

\section{B. METODE PENELITIAN}

Penelitian ini menggunakan jenis penelitian deskriftif (descriftive research), yaitu penelitian yang memberikan gambaran atau uraian atas suatu keadaan sejelas mungkin tanpa ada perlakuan terhadap objek yang di teliti. Desain penelitian yang digunakan adalah cross sectional merupakan metode pengumpulan data dalam penelitian deskriftif dimana informasi yang dikumpulkan pada suatu saat tertentu.

Tabel 1. Definisi Oprasional

\begin{tabular}{|c|c|c|c|c|c|}
\hline Variabel & $\begin{array}{l}\text { Definisi } \\
\text { Operasional }\end{array}$ & Alat Ukur & Cara ukur & $\begin{array}{l}\text { Hasil } \\
\text { Ukur }\end{array}$ & $\begin{array}{l}\text { Skala } \\
\text { Ukur }\end{array}$ \\
\hline $\begin{array}{l}\text { Mutu } \\
\text { pelayanan } \\
\text { dokter } \\
\text { terhadap } \\
\text { kepuasan } \\
\text { pasien } \\
\text { BPJS }\end{array}$ & $\begin{array}{l}\text { Kepuasan: pasien akan } \\
\text { merasa puas apabila } \\
\text { kinerja pelayanan } \\
\text { kesehatan yang } \\
\text { diperoleh sesuai } \\
\text { dengan harapannya. } \\
\text { Cukup puas:pasien } \\
\text { merasa puas akan } \\
\text { pelayanan yang } \\
\text { diberikan namun ada } \\
\text { beberapa pelayanan } \\
\text { atau fasilitas, serta } \\
\text { kinerja yang membuat } \\
\text { pasien sedikit kacewan. } \\
\text { Tidak puas :pasien } \\
\text { yang merasa kecewa } \\
\text { akan pelayanan } \\
\text { kesehatan yang } \\
\text { diharapkan serta pasien } \\
\text { akan complain akan } \\
\text { pelayanan yang } \\
\text { diberikan. }\end{array}$ & $\begin{array}{l}\text { Wawancara } \\
\text { dengan } \\
\text { menggunakan } \\
\text { Koesioner }\end{array}$ & $\begin{array}{l}\text { Kuesioner } \\
\text { yang berisi } \\
\text { pertanyaan } \\
\text { Tentang } \\
\text { penilaian } \\
\text { pasien } \\
\text { terhadap } \\
\text { kepuasan } \\
\text { pasien dalam } \\
\text { pelayanan } \\
\text { yang diberikan } \\
\text { Dokter } \\
\text {-puas: } 6 \\
\text {-Tidak puas: } 5 \\
\text {-Cukup puas:3 }\end{array}$ & $\begin{array}{l}\text { Kategori } \\
\text { kepuasan } \\
\text { pasien: } \\
\text { Baik: } \\
34 \% \\
\text { Cukup } \\
\text { puas 42\% } \\
\text { Kurang: } \\
24 \%\end{array}$ & Ordinal \\
\hline
\end{tabular}


Populasi adalah wilayah generalisasi yang terdiri atas obyek atau subyek yang mempunyai kualitas dan karakteristik tertentu yang ditetapkan oleh peneliti untuk dipelajari dan kemudian ditarik kesimpulannya (Sugiyono. 2005 : 90). Populasi penelitian adalah semua pasien BPJS rawat inap pada bangsal tunjung dan flamboyant penyakit dalam pada Agustus 2017 di Rumah Sakit Umum Daerah Praya yang berjumlah 205 pasien BPJS Kesehatan. Sedangkan sampel adalah bagian dari jumlah dan karakteristik yang dimiliki oleh populasi tersebut. Teknik pengambilan sampel dalam penelitian ini adalah menggunakan accidental sampling yaitu pengambilan sampel yang didasarkan pada kenyataan bahwa mereka kebetulan muncul. Sampel penelitian adalah pasien BPJS yang masih dirawat di ruang rawat inap penyakit dalam Rumah Sakit Umum Daerah Praya sebanyak 60 responden.

Variabel yang terkait dalam penelitian ini adalah mutu pelatanan dokter terhadap kepuasan pasien PBJS di rawat inap penyakit dalam di ruangan tunjung dan flamboyan di Rumah Sakit Umum Daerah Praya.

\section{Teknik Pengumpulan Data}

Menurut ahli metode pengumpulan data berupa suatu pernyataan tentang sifat, keadaan, kegiatan tertentu dan sejenisnya. Pengumpulan data dilakukan untuk memperoleh informasi yang dibutuhkan dalam rangka mencapai tujuan penelitian (Gulo, 2002 : 110). Teknik pengumpulan data penelitian antara lain:
1) Kuesioner.

Kuesioner adalah pernyataan tertulis yang digunakan untuk memperoleh informasi dari responden dalam arti laporan tentang pribadi atau hal-hal yang ia ketahui.

2) Observasi.

Obrservasi merupakan salah satu teknik pengumpulan data yang tidak hanya mengukur sikap dari responden (wawancara dan angket) namun juga dapat digunakan untuk merekam berbagai fenomena yang terjadi (situasi, kondisi). Teknik ini digunakan bila penelitian ditujukan untuk mempelajari perilaku manusia, proses kerja, gejala-gejala alam dan dilakukan pada responden yang tidak terlalu besar.

3) Wawancara.

Wawancara ialah proses komunikasi atau interaksi untuk mengumpulkan informasi dengan cara tanya jawab antara peneliti dengan informan atau subjek penelitian. Dengan kemajuan teknologi informasi seperti saat ini, wawancara bisa saja dilakukan tanpa tatap muka, yakni melalui media telekomunikasi. Pada hakikatnya wawancara merupakan kegiatan untuk memperoleh informasi secara mendalam tentang sebuah isu atau tema yang diangkat dalam penelitian (Emzir, 2010: 50).

\section{HASIL DAN PEMBAHASAN \\ 1. Distribusi Frekuensi Responden}

Tabel 2. Deskripsi Responden Penelitian Berdasarkan Umur

\begin{tabular}{|c|c|c|c|}
\hline No & Umur & N & Persentase \\
\hline 1 & $<20$ & 5 & 10 \\
2 & $20-29$ & 15 & 25 \\
3 & $30-39$ & 20 & 30 \\
4 & $40-49$ & 15 & 25 \\
5 & $>50$ & 5 & 10 \\
\cline { 2 - 4 } & Jumlah & 60 & 100,0 \\
\hline
\end{tabular}


Tabel 2. diatas menunjukkan bahwa dari 60 responden bahwa sebagian besar responden berumur 30 - 39 tahun sebanyak $30 \%$. Hasil penelitian bahwa setengahnya responden yaitu setengahnya mengatakan puas dengan hasil sebagai berikut:

Tabel 3. Distribusi frekuensi responden berdasarkan Keandalan

\begin{tabular}{|c|c|c|c|}
\hline No & Keandalan & N & \% \\
\hline 1 & SP & 15 & 23.51 \\
\hline 2 & P & 25 & 47.1 \\
\hline 3 & TP & 15 & 23.51 \\
\hline 4 & STP & 5 & 5.5 \\
\hline & Jumlah & 60 & 100 \\
\hline
\end{tabular}

Ukuran tingkat kepusan pasien yang pertama adalah kehandalan. Tabulasi data pada Tabel 1 ditemukan bahwa bahwa pasien sangat puas 15 responden $(23.51 \%)$, pasien puas 25 responden $(47.1 \%)$, pasien tidak puas 15 responden $(23.51 \%)$, dan pasien sangat tidak puas 5 responden $(5.5 \%)$.
Berdasarkan hasil wawancara bahwa banyaknya responden mengatakan puas dikarenakan petugas belum profesional dalam menanggapi keluhan pasien terutama pasien yang memakai BPJS kelas tiga. Sehingga pasien belum yakin dengan pelayanan yang diberikan oleh petugas RSUD Praya.

Tabel 4. Distribusi Frekuensi responden berdasarkan Daya Tanggap

\begin{tabular}{|c|c|c|c|}
\hline No & Daya Tanggap & N & \% \\
\hline 1 & SP & 20 & 36.4 \\
\hline 2 & P & 27 & 41.7 \\
\hline 3 & TP & 8 & 14.1 \\
\hline 4 & STP & 5 & 8.5 \\
\hline & Jumlah & 60 & 100 \\
\hline
\end{tabular}

Ukuran tingkat pasien yang kedua adalah daya tanggap. Berdasarkan Tabel 4 ditemukan bahwa pasien sangat puas 20 responden $(36.4 \%)$, pasien puas 27 responden $(41.7 \%)$, pasien tidak puas 8 responden $(14.1 \%)$, dan pasien sangat tidak puas 5 responden $(8.5 \%)$. Berdasarkan hasil wawancara bahwa banyaknya responden mengatakan puas dikarenakan petugas sigap dalam menanggapi keluhan pasien terutama pasien yang memakai BPJS kelas tiga. Sehingga pasien yakin dengan pelayanan yang diberikan oleh petugas RSUD Praya.

Tabel 5. Distribusi Frekuensi responden berdasarkan Assurance

\begin{tabular}{|c|c|c|c|}
\hline No & Assuransi & N & \% \\
\hline 1 & SP & 20 & 36.4 \\
\hline 2 & P & 25 & 40.6 \\
\hline 3 & TP & 10 & 24.1 \\
\hline 4 & STP & 5 & 8.5 \\
\hline & Jumlah & 60 & 100 \\
\hline
\end{tabular}


Ukuran tingkat yang ketiga adalah jaminan. Berdasarkan Tabel 5. ditemukan bahwa pasien sangat puas 20 responden (36.4\%), pasien puas 25 responden (40.6\%), pasien tidak puas 10 responden (24.1\%), dan pasien sangat tidak puas 5 responden (8.5\%). Berdasarkan hasil wawancara bahwa banyaknya responden mengatakan puas dikarenakan petugas sudah menjelaskan semua jaminan yang akan didapat pada saat pelayanan, sehingga banyak pasien yang sudah puas dalam jaminan yang diberikan oleh pihak Rumah Sakit.

Tabel 6. Distribusi Frekuensi responden berdasarkan Emphaty

\begin{tabular}{|c|c|c|c|}
\hline No & Emphaty & $\mathbf{N}$ & \% \\
\hline 1 & SP & 15 & 30.6 \\
\hline 2 & P & 15 & 30.4 \\
\hline 3 & TP & 27 & 41.7 \\
\hline 4 & STP & 3 & 8.5 \\
\hline & Jumlah & 60 & 100 \\
\hline
\end{tabular}

Ukuran tingkat yang keempat adalah emphaty. Berdasarkan Tabel 6. ditemukan bahwa pasien sangat puas 15 responden (30.6\%), pasien puas 15 responden (30.4\%), pasien tidak puas 27 responden $(41.7 \%)$, dan pasien sangat tidak puas 3 responden $(8.5 \%)$. Berdasarkan hasil wawancara bahwa banyaknya responden mengatakan tidak puas dikarenakan petugas masih belum tepat waktu baik itu dalam pendaftaran maupun pelayanan pasien. Petugas diharapkan lebih banyak berperan dalam,membantu pasien memenuhi kebutuhan dasarnya dengan cara membantu langsung, memberikan perhatian lebih, dan mendiskusikan kebutuhan pasien setiap melakukan tindakan yang berhubungan dengan pasien.

\section{Pembahasan}

Kepuasan adalah reaksi emosiaonal terhadap mutu pelayanan yang dirasakan dan kualitas pelayanan yang dirasakan merupakan pendapat menyeluruh atau sikap yang berhubungan dengan keutamaan pelayanan. Pelayanan kesehatan yang berkualitas adalah pelayanan kesehatan yang dapat memuaskan setiap pemakai jasa pelayana kesehatan sesuai dengan tingkat kepuasan rata-rata penduduk serta penyelenggaraan sesuai dengan kode etik dan standar pelayanan profesi yang ada. Untuk menunjang tercapainya kepuasan pasien berdasarkan undang-undang nomor 44 tahun 2009 tentang hak dan kewajiban pasien seorang petugas pelayanan kesehatan harus mengetahui hak-hak pasien dalam pelayanan kesehatan :

1) Memperoleh informasi mengenai tata tertib dan peraturan yang berlaku di rumah sakit.

2) Memperoleh informasi tentang hak dan kewajiban pasien.

3) Memperoleh layanan yang manusiawi, adil, jujur dan tanpa diskriminasi.

4) Memperoleh layanan kesehatan yang bermutu sesuai dengan standar profesi dan standar prosedur operasional.

5) Memperoleh layanan yang efektif dan efisien sehingga pasien terhindar dari kerugian fisik dan materi

Berikut adalah aspek-aspek kepuasan pada pasien :

1) Kenyamanan, aspek ini dijabarkan dalam pertanyaan tentang hal yang menyenangkan dalam semua kondisi, lokasi, kebersihan, kenyamanan ruangan, makan dan minum, peralatan ruangan, tata letak, penerangan, kebersihan, WC/kamar mandi, pembuangan sampah, kesegaran ruangan, dan lain sebagainya.

2) Hubungan pasien dengan petugas, dapat dijabarkan dengan pertanyaan petugas yang mempunyai kepribadian baik yang mendukung jalannya pelayanan yang prima terjadi yang menyangkut keramahan, informasi yang diberikan, sejauh mana tingkat komunikasi, dukungan, tanggapan dokter atau perawat di runagan, keteraturan 
pemberian makanan, obat, pengukuran suhu dan lain sebagainya.

3) Kompetensi teknik petugas, dapat dijabarkan dalam pertanyaan mengenai keterampilan, pengetahuan dan kualifikasi petugas yang baik seperti kecepatan pelayanan pendaftaran, keterampilan dalam penggunaan teknologi, pengalaman petugas medis, gelar medis yang dimiliki, terkenal, keberanian mengambil tindakan, dan lain sebagainya.

4) Biaya, dapat dijabarkan dalam pertanyaan berkaitan dengan jumlah yang harus diberikan atas pelayanan yang telah didapatkan, seperti kewajaran biaya, kejelasan komponen biaya, biaya pelayanan, tingkat masyarakat yang berobat, ada tidaknya keringanan bagi masyarakat miskin (Depkes RI).

Dari hasil pengamatan dan wawancara tingkat kepuasan pasien dapat dijelaskan bahwa ukuran tingkat kepusan pasien yang pertama adalah kehandalan. Tabulasi data pada tabel 1 ditemukan bahwa bahwa pasien sangat puas 15 responden $(23.51 \%)$, pasien merasa sangat puas karena dokter yang bertugas dan petugas medis lainya sudah profesional dalam melayani, pasien puas 25 responden $(47.1 \%)$, pasien merasa puas karena petugas sudah terlatih di bidangnya masing-masing, pasien tidak puas 15 responden (23.51\%), pasien dikatakan tidak puas disebabkan oleh para petugas masih ada yang bekerja tidak sesuai peraturan yang ada di Rumah Sakit, dan pasien sangat tidak puas 5 responden $(5.5 \%)$, pasien sangat tidak puas dikarenakan petugas dalam melayani pasien tidak sesuai dengan SOP yang berlaku di rumah sakit. Berdasarkan hasil wawancara bahwa banyaknya responden mengatakan puas dikarenakan petugas sudah profesional dalam menanggapi keluhan pasien terutama pasien yang memakai BPJS kelas tiga. Sehingga pasien sudah yakin dengan pelayanan yang diberikan oleh petugas RSUD Praya

Ukuran tingkat pasien yang kedua adalah daya tanggap. Berdasarkan tabel ditemukan bahwa pasien sangat puas 20 responden (36.4\%), pasien sangat puas dengan pelayanan karena daya tanggap dokter begitu cepat sehingga memberikan rasa nyaman pada pasien, pasien puas 27 responden $(41.7 \%$ ), pasien puas sudah merasa pelayanan yang diberikan dokter maupun perawat/petugas medis lainya merospen sangat cepat jika ada keluhan, pasien tidak puas 8 responden $(14.1 \%)$, pasien tidak puas dikarenakan ada petugas yang masih training yang melayani pasien, dan pasien sangat tidak puas 5 responden $(8.5 \%)$, pasien sangat tidak puas dikarenakan daya tanggap dokter dan petugas medis lain masih sangat kurang. Berdasarkan hasil wawncara bahwa banyaknya responden mengatakan puas dikarenakan petugas sigap dalam menanggapi keluhan pasien terutama pasien yang memakai BPJS kelas tiga. Sehingga pasien sudah yakin dengan pelayanan yang diberikan oleh petugas RSUD Praya.

Ukuran tingkat yang ketiga adalah assuransi. Berdasarkan tabel ditemukan bahwa pasien sangat puas 20 responden $(36.4 \%)$, pasien dikatakan sangat puas karena dalam pelayanan kesehatan dokter maupun petugas medis lain melayani pasien dengan sangat baik, lemah lembut dan ramah serta tidak membedakan antara pasien yang satu dengan pasien yang lain, pasien puas 25 responden (28.2\%), pasien puas dikarenakan petugas kesehatan atau dokter melayani pasien sesuai dengan ramah, pasien tidak puas 10 responden (24.1\%) pasien tidak puas dikarenakan petugas atau dokter dalam melakukan pelayanan masih belum sesuai dengan aturan dan dokter atau petugas kesehatan lain kurang ramah kepada pasien, dan pasien sangat tidak puas 5 responden $(8.5 \%)$, pasien dikatakan sangat tidak puas karena pelayanan dokter atau petugas kesehatan lain sangat tidak wajar seperti petugas dalam melkukan pelayanan tanpa senyum dan tidak bersikap ramah kepada pasien. Berdasarkan hasil wawncara bahwa banyaknya responden mengatakan puas dikarenakan petugas sudah menjelaskan semua jaminan yang akan didapat pada saat pelayanan, sehingga banyak pasien yang sudah mengerti 
dalam jaminan yang diberikan oleh pihak Rumah Sakit.

Ukuran tingkat yang keempat adalah emphaty. Berdasarkan tabel ditemukan bahwa pasien sangat puas 15 responden (30.6\%), pasien dikatakan sangat puas karena kepedulian dan perhatian dokter dalam melayani psien sangat bagus, pasien puas 15 responden (30.4\%), pasien dikatakan puas karena mendapat perhatian yang cukup baik dari dokter dan petugas kesehatan lain, pasien tidak puas 27 responden (41.7\%), pasien dikatakan tidak puas karena kurangnya perhatian dari dokter atau tenaga kesehatan lain yang merawat pasien dan pasien sangat tidak puas 3 responden $(8.5 \%)$, pasien dikatakan sangat tidak puas karena dokter dan tenaga kesehatan lain kurang memberikan pengertian dan kepedulian sesuai dengan aturan yang telah ditetapkan. Berdasarkan hasil wawancara bahwa banyaknya responden mengatakan tidak puas dikarenakan petugas masih belum tepat waktu baik itu dalam pendaftaran maupun pelayanan pasien, dokter diharapkan lebih banyak berperan dalam membantu pasien memenuhi kebutuhan dasarnya dengan cara membantu langsung, memberikan perhatian lebih, dan mendiskusikan kebutuhan pasien setiap melakukan tindakan yang berhubungan dengan pasien.

\section{KESIMPULAN}

Berdasarkan hasil identifikasi yang telah dilakukan, disimpulkan bahwa tingkat kepuasan pasien terhadap pelayanan dokter dari segi keandalan, daya tanggap, asuransi dan empathy dapat dikelomopkkan dalam kategori pasien yang sangat puas, pasien yang puas, pasien yang tidak puas dan pasien yang sangat tidak puas. Oleh karena itu, rumah sakit perlu menghimbau: (i) Dokter Umum RSUD Praya harus lebih memperhatikan tentang kualitas pelayanan yang diberikan kepada pasien BPJS agar Rumah Sakit semakin berkembang, selain itu, Dokter harus selalu menerapkan senyum, sopan, santun setiap melakukan tindakan atau pemeriksaan (ii) Untuk petugas ruangan Rawat Inap penyakit dalam dan dokter umum RSUD Praya harus lebih cepat dan sigap dalam merespon pasien BPJS.

\section{DAFTAR PUSTAKA}

[1] Azrul, Azwar (2010). Pengantar Administrasi Kesehatan. Tangerang: Bina Pura Aksara.

[2] Depkes RI. (2006). Pedoman Penyelenggaraan Dan Prosedur Rekammedis Rumah Sakit Di Indonesia Revisi II.

[3] Hatta, Gemala (2011). Pedoman Manajemen Informasi Kesehatan Di Sarana Pelayanan Kesehatan. Jakarta: UI-Press.

[4] Hosizah (2014). Kumpulan peraturan perundangan RMIK (MIK). Yogyakarta: Apti RMIK.

[5] Julianna (2008). Kepuasan Pelanggan. Jakarta: EGC.

[6] Mukti (2007). Mutu Pelayanan Kesehatan. Jakarta: Bina Husada

[7] Nazir, Mohammad (2005). Desain Penelitian. Jakarta: Bina Husada.

[8] Notoatmodjo, Soekidjo (2012). Metodologi Penlitian Kesehatan. Jakarta: Rineka Cipta.

[9] Nursalam (2003). Kerangka Kerja. Jakarta: Bina Husada.

[10] Revens (1986). Mutu Pelayanan Rawat Inap. Surabaya: Airlangga.

[11] Siagaan, P Sondang (2004). Administrasi Kesehatan. Surabaya: Bina Husada.

[12] Tjiptono F. (2005). Mutu Pelayanan Kesehatan. Jakarta: Bina Husada. 